\title{
ECONOMIC, SOCIAL AND ENVIRONMENTAL FEATURES OF USE OF LAND RESOURCES IN UKRAINE AND WORLD
}

\author{
Nadiia Bahan'
}

\begin{abstract}
The purpose of the article is to study the economic, social and environmental features of the use of land resources of agricultural enterprises, which is one of the determining factors of economic development and environmental safety of the state. Optimization of the use of land resources in ecological, economic and social aspects is the basis for a favourable territorial environment of natural landscapes. The goal of the article is to study the economic efficiency of the use of land resources in modern conditions, their social and environmental basis. Methodology. To write the article, methods of analysis, comparison, and generalization of research results, economic, statistical and graphic methods have been used. It is clear that research on the efficiency of the use of land resources in agricultural enterprises is a complex and lengthy process. Taking this into account, it is impossible to identify a single indicator that can fully reflect the level of efficiency in the use of land resources. For a more complete characterization of the specified process, a system of both natural and value indicators should be used. Results. According to the results of the study, it has been established that the practice of land use and the state of study of certain problems require further study of the prerequisites for the development of processes of soil degradation caused by the main factors: human economic activity, climatic, relief and ground conditions. Attention is drawn to the efficiency of the use of land resources in agricultural enterprises of Ukraine; the distribution of enterprises in Ukraine is carried out by the size of agricultural land. The role of state financing of enterprises in the sector of agro-industrial development is analysed, and the state of financing of programs to support agro-industrial production in 2019 is considered. The social aspects of land use in Ukraine are processed; they are focused on the quality of food, ensuring the welfare of the population and landscaping of rural municipalities. The program of support of the agro-industrial production sector by providing loans to agrarians has been investigated: in particular, it is planned to allocate 1,200,000,000 UAH for a programme to reduce the cost of loans to enterprises engaged in all types of agricultural activities. Practical implications. Since the practice of managing agricultural enterprises in market conditions shows that the most important thing is not the availability of land resources but the efficiency of using its potential; therefore, the need to create a reliable economic mechanism that will ensure the effective use of land resources and preserve their fertility is a priority. The breadth and versatility of land problems, their connection and dependence on socio-economic, political and environmental factors necessitate further research on this issue.
\end{abstract}

Key words: land resources, environmental factors, social aspects, land use efficiency, government support.

JEL Classification: O13, O57, Q15, Q24

\section{Introduction}

Ukraine has a significant and high-quality potential of land resources, which in recent years has been decreasing its return and losing its quality natural properties. The presence and diversity of natural resources increase the capabilities of the state and help occupy an appropriate place among other countries of the world. Ukraine ranks sixth among the countries of the world with the largest land reserve and first in the ranking of the ratio of arable land to the total area of the country.

\footnotetext{
Corresponding author:

${ }^{1}$ Poltava State Agrarian Academy, Ukraine.

E-mail: bahan.pdaa@gmail.com

ORCID: https://orcid.org/0000-0003-2843-5893
}

During the period of land reform in Ukraine, the composition and structure of the land fund is changing. In this regard, labor, capital, science, entrepreneurial activity of natural resources are especially important in economic terms, but they lead to a number of environmental, economic and social problems, the most important of which are ineffective land use, non-irrigation of lands, a decrease in the level of agricultural production, the absence of real land values, degradation, manifestations of water and wind erosion and the 
like. Accordingly, in 2020, the Verkhovna Rada adopted a bill that should open the agricultural land market in Ukraine in the second reading.

The study of the issue of rational, economically feasible, environmentally safe use and protection of land resources is given considerable attention in the works by I. K. Bystriakov, V. V. Horlachuk, L. M. Berezina, D. S. Dobriak, Sh. I. Ibatullin, Yu. L. Koval, A. H. Martyn, A. Ya. Sokhnych, A. M. Tretiak, M. A. Khvesyk and other scientists. The problems of reforming land relations, taking into account environmental and economic criteria, are studied in their publications by well-known Russian scientists V. M. Budziak, A. H. Martyn and others. The results of scientists' research cover a wide range of this problem. Some of them studied in detail the role and importance of land resources in the system of expanded reproduction of national wealth, others studied the development of land relations and their impact on the level of land use efficiency.

\section{Land resources of Ukraine and the world}

The earth, as a product of nature, among other material conditions, is the first prerequisite and natural basis of production. With its soil cover, mineral resources, forests, waters, it occupies the main place in the development of social production and productive forces. As a natural resource, it is an integral part and the main feature of the production potential of agricultural enterprises, it is the natural and economic basis for the production of material goods necessary for the existence of people and the development of society. Therefore, agricultural production should be combined with a system of economic and environmental measures aimed at its reproduction, protection and rational use.

The need for effective use of land resources is also due to the fact that they provide the vital activity of the population of the state, create raw materials for the processing industry. Thus, land resources, namely their efficient use, constitutes the basis for the country's food security. Rational use of land resources with the use of environmental protection measures will never lose its relevance, because the country's independence in the modern world is primarily determined by food security, which can be achieved only when sustainable use of land resources is ensured (Melnychuk, 2015).

Reforming the agrarian sector of the economy creates opportunities for increasing the number of land users, the level of land use and production volumes. However, the degree of use of agricultural land in many enterprises still remains at a rather low level.

Agricultural enterprises with agricultural land at their disposal are located throughout Ukraine. The largest number of such enterprises is observed in the central and southern regions and makes $30 \%$ of the total. The smallest one is located in the eastern and northern part of Ukraine and makes 9-11\%.

Now the issue of increasing the economic efficiency of the use of natural resources is of paramount importance, therefore an effective system of agricultural land use should be based on the protection and expanded reproduction of land and resource potential (Melnychuk, 2015).

Let us conduct a study of the land resources of Ukraine in comparison with foreign countries (Table 2).

Ukraine ranks sixth among the countries with the largest land reserves and tops the rating with the ratio of arable land to total land area with $71.87 \%$.

Consider the amount of land resources per 1 inhabitant in Ukraine and foreign countries (Figure 1).

Table 1

Distribution of enterprises in Ukraine by the size of agricultural land, 2017

\begin{tabular}{|c|c|c|c|c|}
\hline \multirow{2}{*}{ Regions } & \multicolumn{2}{|c|}{ Number of enterprises } & \multicolumn{2}{c|}{ Agricultural land area } \\
\cline { 2 - 5 } & Units & to the total number, $\%$ & thousand hectares & to the total area, \% \\
\hline Central region & 14099 & 31.06 & 10172.5 & 25.65 \\
\hline Northern region & 5212 & 11.48 & 6926.6 & 17.46 \\
\hline Southern region & 14043 & 30.94 & 8805.3 & 22.20 \\
\hline Western region & 7694 & 16.95 & 7397.9 & 18.65 \\
\hline Eastern region & 4339 & 9.56 & 6362.5 & 16.04 \\
\hline Ukraine & 45387 & 100.00 & 39664.8 & 100.00 \\
\hline
\end{tabular}

Source: calculated by the author according to the data (Derzhavna sluzhba statystyky Ukrainy, 2017) 
Table 2

Top 20 largest land reserves of the planet

\begin{tabular}{|c|c|c|c|c|c|}
\hline $\begin{array}{l}\text { Place in the } \\
\text { ranking of } \\
\text { arable land }\end{array}$ & $\begin{array}{l}\text { Name of } \\
\text { country }\end{array}$ & $\begin{array}{l}\text { The area of arable land } \\
\text { (million hectares) }\end{array}$ & $\begin{array}{l}\text { General area of the } \\
\text { country } \\
\text { (million hectares) }\end{array}$ & $\begin{array}{l}\text { The ratio of arable land } \\
\text { to the total area of the } \\
\text { country }\end{array}$ & $\begin{array}{l}\text { Place in the ranking } \\
\text { of arable land } \\
\text { to the general area } \\
\text { of the country }\end{array}$ \\
\hline 1 & India & 179,800 & 328,726 & 54.70 & 4 \\
\hline 2 & USA & 167,756 & 983,151 & 17.06 & 13 \\
\hline 3 & China & 165,228 & 960,001 & 17.21 & 12 \\
\hline 4 & Russia & 155,799 & 1709,825 & 9.11 & 17 \\
\hline 5 & Brazil & 63,994 & 851,577 & 7.51 & 18 \\
\hline 6 & Ukraine & 43,375 & 60,355 & 71.87 & 1 \\
\hline 7 & Canada & 42,980 & 987,975 & 4.35 & 20 \\
\hline 8 & Argentina & 38,383 & 278,040 & 13.80 & 14 \\
\hline 9 & Indonesia & 37,441 & 191,682 & 19.53 & 9 \\
\hline 10 & Nigeria & 35,655 & 92,377 & 38.60 & 7 \\
\hline 11 & Australia & 35,105 & 774,122 & 4.53 & 19 \\
\hline 12 & Mexico & 34,516 & 196,438 & 17.57 & 11 \\
\hline 13 & Turkey & 34,314 & 78,535 & 43.69 & 6 \\
\hline 14 & Iran & 33,063 & 174,515 & 18.95 & 10 \\
\hline 15 & France & 31,795 & 54,909 & 57.90 & 3 \\
\hline 16 & Spain & 31,786 & 50,594 & 62.83 & 2 \\
\hline 7 & Kazakhstan & 25,885 & 272,490 & 9.50 & 16 \\
\hline 18 & Thailand & 25,756 & 51,312 & 50.19 & 5 \\
\hline 19 & Ethiopia & 25,702 & 110,430 & 23.27 & 8 \\
\hline 20 & Sudan & 22,740 & 188,225 & 12.08 & 15 \\
\hline
\end{tabular}

Source: (Hoshtynar, 2020)

Thus, the highest percentage of land resources per capita is observed in Canada $-28.6 \%$ and Russia $11.9 \%$, which is due to the large land areas of the countries.

Consider the arable land of individual states (Figure 2).
Among the studied countries, Russia, China and the United States have the highest arable land areas. They are among the twenty countries with the largest land reserves of the planet, but their place in the overall ranking (Table 2) indicates that agriculture is not their main field of activity.

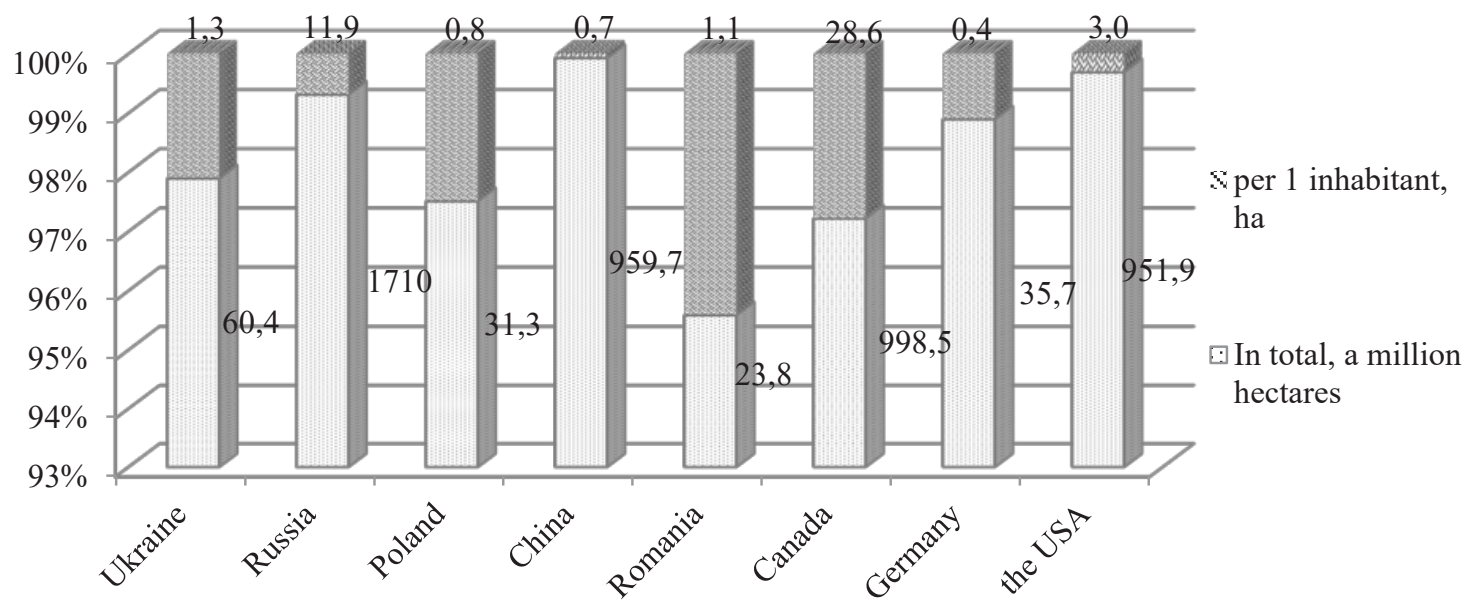

Figure 1. Land resources of Ukraine and foreign countries, 2017

Source: has been generalized by the author (AgroPolit.com, 2019) 


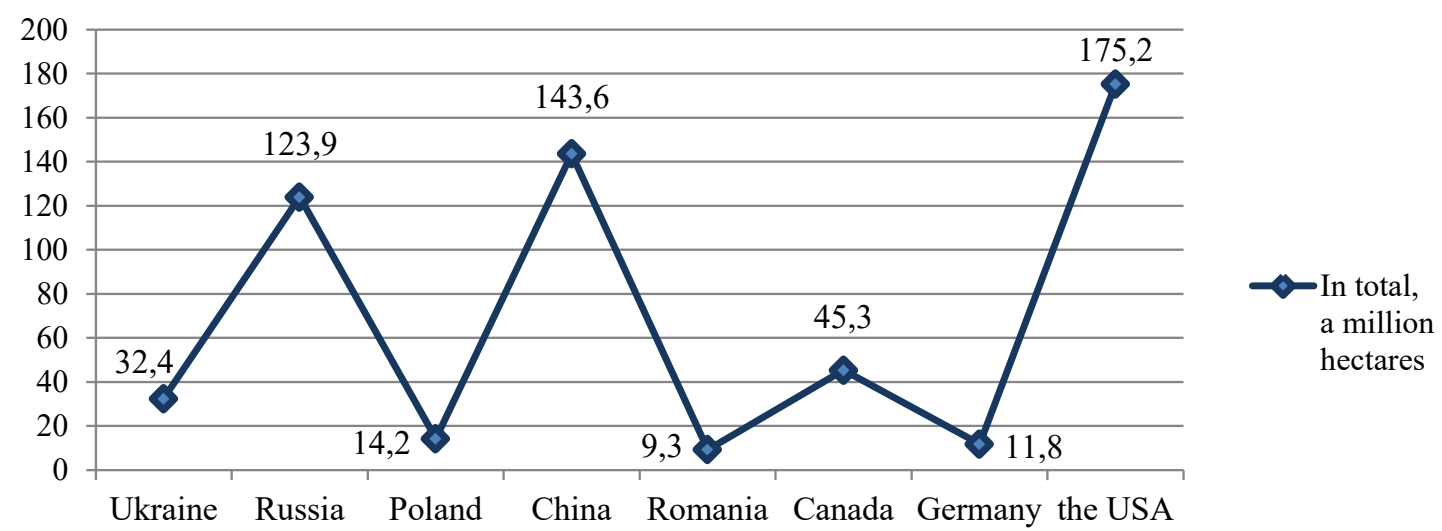

Figure 2. Arable land of individual states, 2017

Source: has been generalized by the author (AgroPolit.com, 2019)

\section{Environmental and social features of the use of land resources}

In Ukraine, more than $60 \%$ of the country's land fund is made up of unique chernozem soils. In general, there are about 800 types of soils, but the modern use of land resources in Ukraine does not meet the requirements of rational environmental management, and as a result, soils lose their fertility and degrade. The most widespread are dehumification and a decrease in the content of nutrients in soils, physical degradation (overconsolidation), erosion, pollution and the like. Let us examine the main types of soil degradation in Ukraine in more detail (Figure 3).

According to official institutions, the area of degraded land ranges from 8 million hectares to 10-15 million hectares, which entails consequences for agricultural production, in particular, crop yields are reduced by $10-30 \%$, and more, and losses only due to the shortfall in agricultural products is up to 35 billion UAH per year. The ecological and economic damage from degradation is estimated at about 40 billion $\mathrm{UAH}$ (AgroPRO, 2021).

Excessive agricultural development and ploughing of the territory is one of the main factors destabilizing the ecological situation in Ukraine. These problems need to be solved in land management projects on an ecological and landscape basis of agricultural enterprises, which should include: optimization of the composition of land; organization of arable land, natural forage

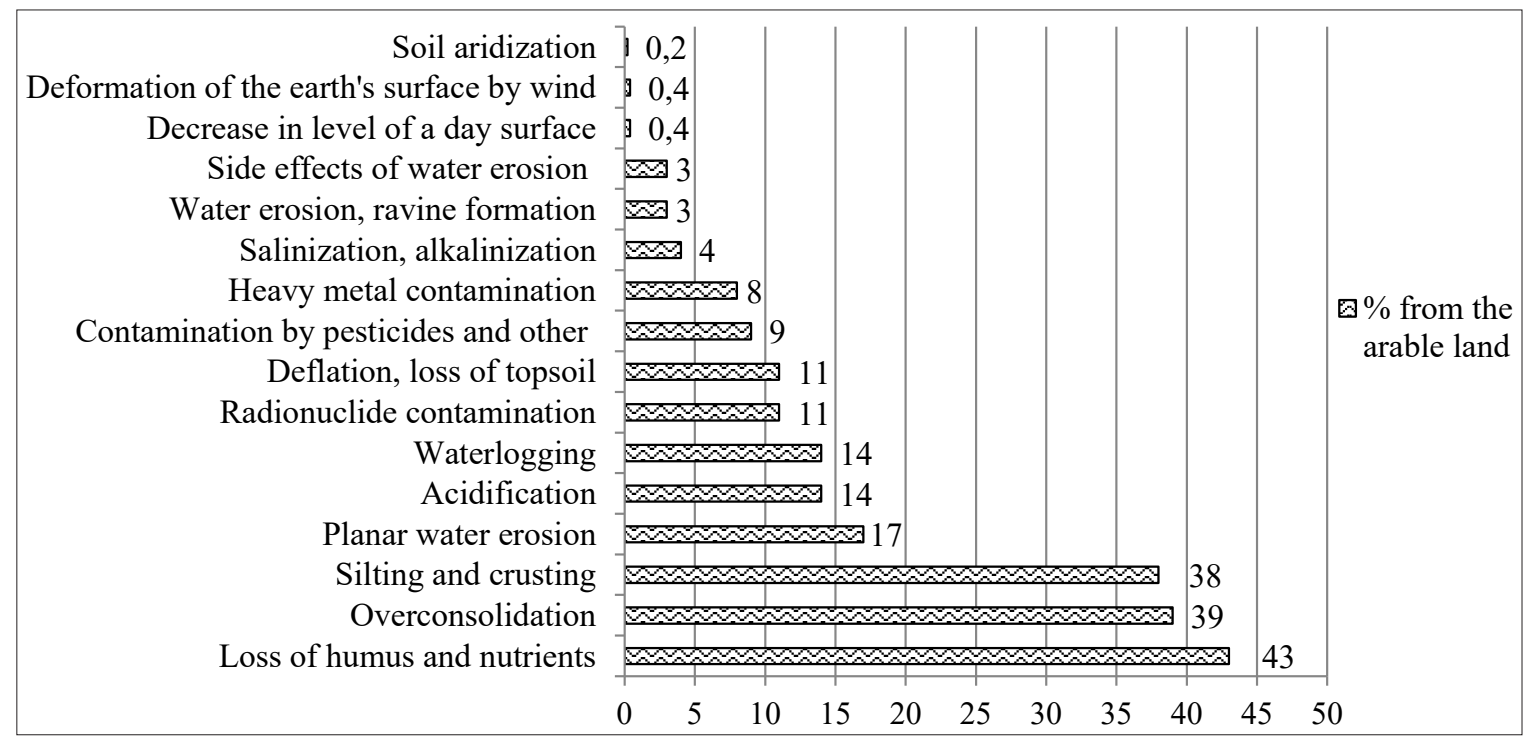

Figure 3. The main types of soil degradation in Ukraine

Source: (AgroPolit.com, 2019) 


\begin{tabular}{|c|c|c|}
\hline \multicolumn{2}{|c|}{ Social aspects of the use of land resources in Ukraine: } \\
\cline { 2 - 3 } \begin{tabular}{c|c|} 
quality of food products \\
obtained as a result of \\
agricultural production
\end{tabular} & $\begin{array}{c}\text { welfare of the } \\
\text { population of rural } \\
\text { municipalities }\end{array}$ & $\begin{array}{c}\text { arrangement of territories of } \\
\text { rural municipalities }\end{array}$ \\
\cline { 2 - 3 } $\begin{array}{c}\text { The introduction of various } \\
\text { kinds of fertilizers entails a } \\
\text { violation of the natural } \\
\text { balance in the ecological } \\
\text { system of the soil and, as a } \\
\text { consequence, the excess of } \\
\text { the content of a number of } \\
\text { components (nitrates, } \\
\text { phosphates, etc.) in }\end{array}$ & $\begin{array}{c}\text { The goal of the socio- } \\
\text { economic development } \\
\text { of municipalities is to } \\
\text { improve the well-being } \\
\text { of citizens living there } \\
\text { for improving living } \\
\text { conditions and ensuring } \\
\text { the budgetary efficiency } \\
\text { of agricultural producers } \\
\text { and municipalities. }\end{array}$ & $\begin{array}{c}\text { Social development of rural } \\
\text { areas provides for the } \\
\text { systematization of the activities } \\
\text { of state authorities, local self- } \\
\text { government, economic entities } \\
\text { and the population in the region, } \\
\text { the creation of a modern } \\
\text { engineering infrastructure, the } \\
\text { economic conditions of } \\
\text { management, health care, } \\
\text { education and culture }\end{array}$ \\
\hline
\end{tabular}

Figure 4. Social aspects of the use of land resources in Ukraine

Source: developed by the author (Gharnagha, 2017)

lands with minimal environmental damage; compensation for unreasonably privatized, degraded and unproductive lands; mechanisms for the use of land shares (shares) in accordance with the new organization of the territory (AgroPolit.com, 2019).

Degradation of agricultural land in Ukraine has become a threat to national food security. To a large extent, this situation is due to the loss of the economic interest of the land user in environmentally friendly land use and requires an immediate justification of a clear solution mechanism.

\section{State support for agro-industrial production}

In recent years, the economy of our country has been developing mainly due to the agricultural sector. Agricultural producers for the implementation of their current economic activities, the introduction of the latest technologies, renewal and expansion of the material and technical base require significant amounts of financial resources. Although, there are many financial instruments in the Ukrainian market, farmers mainly use funds from their own sources to operate. However, these funds are not enough to implement the full development of enterprises and ensure their expanded reproduction; therefore, in these conditions, the role of state support for agricultural producers increases. During 2019-2021, state support for enterprises in the industry has undergone significant changes: it has been characterized by small volumes of direct government support and the establishment of a value added tax rate on the sale of certain types of agricultural products in the amount of $14 \%$ from March 1 , 2021 (AgroPRO, 2021).

According to the information and analytical portal of the agro-industrial complex of Ukraine in 2019, financial support to farmers was mainly aimed at supporting the livestock industry (Table 3).

It was envisaged to provide loans to agrarians who were engaged in all types of agricultural activities. Currently, only entities that are engaged in animal husbandry and use credit funds for animal husbandry or who have a net income from the sale of products for the last year of 20 million UAH have such access (Ministry for Development of Economy, Trade and Agriculture of Ukraine, 2020).

In the state budget for 2020, an amount of 4.2 billion UAH is fixed to support the agricultural industry, of which 1.2 billion UAH is expected to be allocated for a programme to reduce the cost of loans. In particular, the programme includes (Ministry for Development of Economy, Trade and Agriculture of Ukraine, 2020):

- compensation of interest on loans for agricultural enterprises with an annual turnover of up to 20 million UAH. This direction will not have restrictions on the intended use of loans. The state 
Table 3

The state of financing of programmes to support agro-industrial production in 2019, million UAH

\begin{tabular}{|c|c|c|c|}
\hline Program / direction & $\begin{array}{l}\text { Directed in } \\
2018\end{array}$ & $\begin{array}{l}\text { Scheduled } \\
\text { for } 2019\end{array}$ & $\begin{array}{c}\text { Done, } \% \\
\text { (on } 11 / 13 / 2019 \text { ) }\end{array}$ \\
\hline $\begin{array}{l}\text { Total: } \\
\text { including: }\end{array}$ & 4166 & 5908 & $\mathrm{X}$ \\
\hline $\begin{array}{l}\text { State support for the livestock industry, storage and processing of } \\
\text { agricultural products, aquaculture (fish farming) }\end{array}$ & 2390 & 3500 & 45.7 \\
\hline Financial support for agricultural producers & 913 & 882 & 72.6 \\
\hline Financial support for the development of farms & 204 & 800 & 28.8 \\
\hline $\begin{array}{l}\text { State support for the development of hop growing, the establishment } \\
\text { of young orchards, vineyards and berry fields, supervision of them }\end{array}$ & 394 & 400 & 29.9 \\
\hline $\begin{array}{l}\text { Financial support for activities in the agro-industrial complex by } \\
\text { reducing the cost of loans }\end{array}$ & 266 & 127 & 81.7 \\
\hline Providing loans to farms & - & 200 & 70.0 \\
\hline
\end{tabular}

Source: (Landlord, 2019)

will compensate up to $1.5 \%$ of the discount rate of the National Bank of Ukraine, the final cost of a loan for an agricultural producer will not exceed $5 \%$;

- compensation of interest on loans attracted for the development of animal husbandry, including "niche" areas - sheep breeding, goat breeding, beekeeping, fur farming, etc. It is assumed that the amount of loans should not exceed 10-15 million UAH;

- compensation of interest on loans attracted for the purchase of agricultural land. The direction will apply to agricultural producers of various forms of farming. The amount of compensation interest will not exceed 5 million UAH per year. Now in Ukraine there are 38 authorized banks through which the state support program is being implemented.

State support should be as accessible as possible and be of a systemic and increasing nature, which will make it possible to fully use the existing agricultural potential.

\section{Economic aspects of the use of land resources}

Under the economic aspects of the use of land resources, we primarily mean:

- transferability (transfer of rights to land from one person to another by succession or otherwise);

- forms of ownership and management (determine legal issues of land use, organizational and technological conditions of agricultural production);

- the cost of land resources as a measure of materialized labor (necessary to maintain sustainable and effective development of agricultural production) (Gharnagha, 2017).
Land management is impossible without reliable information on the qualitative characteristics of each specific site, its biological and economic fertility, since ignoring or incorrectly assessing its potential can negate the planning results, is one of the main management functions. A study on the issue of land reform is now coming into force.

According to the Ministry for Development of Economy, Trade and Agriculture of Ukraine, the positive consequences of the land reform will be: an increase in the income of rural residents, fair rules of the game for legal investors; the development of farming and small-scale agricultural production; an increase in funds for the repair of rural roads, schools and hospitals; taxes on pensions and salaries of state employees; establishment of market, not corrupt prices for land.

\section{Conclusions}

The analysis of the economic, social and environmental features of the use of land resources in Ukraine shows the following results:

1. In Ukraine, there is a varied amount of land resources, which helps occupy a leading position among other countries of the world. It ranks sixth among the countries of the planet with the largest land reserves and tops the rating of the ratio of arable land to the total area of the country with an indicator of $71.87 \%$. Enterprises engaged in agricultural activities are located throughout Ukraine; the largest number of them is concentrated in the central region.

2. More than $60 \%$ of the land fund of the country is made up of chernozem soils, which eventually 
lose their fertility and degrade. Therefore, in order to preserve the soil cover, we recommend using the principles of ecological landscape farming, in which the ratio of agricultural land and natural complexes will be economically feasible and environmentally justified.

3. The social aspects of the use of land resources are the control over the quality of food products obtained as a result of agricultural production, ensuring the well-being of the population of rural municipalities and the arrangement of their territories.
4. State support for enterprises in the sector of agro-industrial production is undergoing significant changes: the volume of support is growing; from March 1, 2021, the value added tax rate has been set for the sale of certain types of agricultural products in the amount of $14 \%$.

5. The provision of loans to farmers who are engaged in all types of agricultural activities: in the state budget for 2020, the amount of $1,200,000,000 \mathrm{UAH}$ is fixed for the program to reduce the cost of loans.

\section{References:}

AgroPolit.com Hot agricultural policy (2019). Hruntovi resursy Ukrainy: suchasnyi stan, dehradatsiia, okhorona [Soil resources of Ukraine: current state, degradation, protection]. Available at: https://agropolit.com/infogra phics/view/93 (accessed 23 February 2021).

AgroPolit.com Hot agricultural policy (2019). Khto vbyvaie ukrainski zemlu, abo yak zupynyty dehradatsiiu hruntiv [Who is killing Ukrainian lands, or how to stop soil degradation]. Available at: https://agropolit.com/spetsproekty/566-hto-vbivaye-ukrayinski-zemli-abo-yak-zupiniti-degradatsiyugruntiv (accessed 25 February 2021).

AgroPRO (2021). Z 1 bereznia Stavka PDV pry realizatsii okremykh vydiv silhospproduktsii -14 \% [From March 1, the VAT rate on the sale of certain types of agricultural products - 14\%]. Kyiv: АгроPRO, vol. 4, no. 4, pp. $2-4$.

Derzhavna sluzhba statystyky Ukrainy (2017). Ekonomichna statystyka [Economic statistics]. Kyiv. Available at: http://www.ukrstat.gov.ua/ (accessed 10 March 2021).

Gharnagha A. N., Kushnir N. B., \& Ihnatiuk I. Z. (2017). Orhanizatsiia efektyvnoho zbalansovanoho vykorystannia zemli [Organization of effective balanced land use]. Economy and society, no. 9, pp. 819-825.

Hoshtynar, S. L. (2020). Zarubizhnyi dosvid rehuliuvannia rynku zemli ta mozhlyvosti yoho adaptatsii v Ukraini pry rozhliadi pytannia pro skasuvannia moratoriiu na prodazh zemli [Foreign experience in regulating the land market and the possibility of its adaptation in Ukraine when considering the issue of lifting the moratorium on land sales]. Legal scientific electronic journal, no. 3, pp. 174-178.

Landlord (2019). Derzhpidtrymka APK u 2019 rotsi: skilky koshtiv vykorystano (infohrafika) [State support of agro-industrial complex in 2019: how much money was used (infographic)]. Available at: https://landlord.ua/news/derzhpidtrymka-apk-u-2019-rotsi-skilky-koshtiv-vykorystano-infohrafika/ (accessed 17 March 2021).

Melnychuk, L. S. (2015). Efektyvnist vykorystannia zemelnykh resursiv silskohospodarskykh pidpryiemstv [Use of land resources efficiency by agricultural enterprises]. Sustainable economic development. International research and production journal, no. 71, pp. 135-140.

Ministry for Development of Economy, Trade and Agriculture of Ukraine (2020). Uriad nadav dustup do derzhavnoi pidtrymky bilshii kilkosti ahrariiv [Government gives access to state support for a larger agriculture]. Kyiv: Government portal The only web portal of the executive authorities of Ukraine. Available at: https://www.me.gov.ua/News/Detail?lang=uk-UA\&id=868faf96-7c81-41bc-8e2b-8c7471 a0e8d5\&title=UriadNadavDostupDoDerzhavnoiPidtrimkiBilshii (accessed 12 March 2021).

Ministry for Development of Economy, Trade and Agriculture of Ukraine (2020). Derzhavna pidtrymka apk-2020: prohrama zi zdeshevlennia kredytuvannia pratsiuvatyme za trioma napriamamy [State support of apc-2020: program for cheaping loans will work in three directions]. Kyiv: Press Service of the Ministry of Economy. Available at: https://www.me.gov.ua/News/Detail? lang=ukUA\&id=409b0030-c4de-490f-8fb9-40ccdea42010\&title=DerzhavnaPidtrimkaApk2020ProgramaZiZdeshevlenniaKredituvanniaPratsiuvatimeZaTromaNapriamami (accessed 14 March 2021). 